\title{
PENGUATAN MODAL SOSIAL KELEMBAGAAN DALAM PENANGGULANGAN KEMISKINAN PERDESAAN DI PANTAI UTARA DAN PANTAI SELATAN
}

\author{
STRENGTHENING INSTITUTIONAL SOCIAL CAPITAL IN RURAL POVERTY \\ TREATMENT ON THE NORTH BEACH AND SOUTH BEACH
}

\author{
Mursid Zuhri \\ Badan Perencanaan Pembangunan, Penelitian dan \\ Pengembangan Daerah Provinsi Jawa Tengah \\ Jl. Pamuda No. 127-133 Semarang, Jawa Tengah \\ E-mail: zmursid 2010@yahoo.co.id
}

Diterima: 25 Maret 2020, Direvisi: 15 April 2020, Disetujui: 26 Mei 2020

\begin{abstract}
ABSTRAK
Penelitian ini bertujuan untuk mempelajari peran modal sossial pada aktivitas nelayan miskin, jaringan sosial masyarakat nelayan, kelembagan yang dibangun terutama kelembagaan ekonomi, serta menyusun gambaran model pengembangan kelembagaan untuk pemberdayaan nelayan miskin di Kabupaten Kebumen, Kabupaten Brebes, Kota Pekalongan, Kabupaten Batang dan Kabupaten Rembang. Penelitian ini menggunakan metode penelitian mixed method kualitatif dan kuantitatif. Hasil penelitian menunjukkan bahwa (a) Modal alam (natural capital) pada sebelas desa sampel berupa pesisir dan lautan, dan mayoritas penduduk berpendidikan formal Sekolah Dasar (SD) dan sebagian tidak tamat SD serta berpendapatan rendah. (b) Interaksi yang lancar didukung hubungan sosial berdasarkan ikatan ketetanggaan, kekerabatan, dan keagamaan (c) Desa yang memiliki modal sosial yang paling kuat adalah Desa Tasikagung, kemudian disusul Desa Klidang Lor Kota Pekalongan, Celong Kedawung Kabupaten Batang dan Pasir Kabupaten Kebumen. Pada masyarakat desa yang memiliki modal sosial yang relatif kuat maka tingkat kesejahteraaan masyarakat cenderung tinggi dan proses transformasi sosial-ekonominya berlangsung lebih cepat. (d) Implementasi program belum mampu menjangkau warga miskin, yang semakin tidak berdaya; tidak terjadi transfer daya, karena program lebih dimanfaatkan oleh golongan masyarakat yang lebih mampu dan berpengaruh; transfer daya hanya terjadi di tingkat kelembagaan lokal yang didominasi oleh kalangan dekat kekuasaan; dan relatif tidak terjadi proses belajar sosial, karena kegiatan program lebih bernuansa ekonomis. (e) Kekuatan budaya nonmaterial atau modal sosial menjadi faktor penting mengapa masyarakat di sebelas desa sampel hinga sekarang masih bisa bertahan. Makna terbentuknya rasa saling percaya (mutual trust) adalah hasil interaksi yang melibatkan (paling tidak antar tiga) anggota masyarakat dalam suatu kelompok ketetanggaan, asosiasi tingkat dukuh, organisasi tingkat desa, dan berkembangnya sistem jaringan sosial hingga melintasi batas desa. (f) Program pemberdayaan dipengaruhi oleh kekuatan modal sosial yang dibangkitkan oleh sejumlah tata nilai (komposit) yang membentuk jaringan mutual trust, mutual respect dan mutual benefit. Rekomendasi yang dapat diberikan : (a) penguatan modal sosial seperti rasa malu/harga diri, empati, kejujuran, amanah, altruism, bervisi ke depan dan rasional menjadi penting diperhatikan; sedangkan untuk penggerak kemajuan material adalah kerja keras dan rajin, hemat, gandrung inovasi, menghargai prestasi kerja, bervisi ke depan, dan rasional. b) pemberdayaan masyarakat pedesaan terutama warga nelayan miskin melalui penguatan modal sosialnya perlu diletakkan dalam kerangka transformasi atau pembangunan masyarakat pedesaan secara berkelanjutan (c) pengembangan wilayah pesisir harus memperhatikan hubungan sosial dalam masyarakat nelayan, agar tidak mengarah pada polarisasi sosial. (d) faktor kepemimpinan
\end{abstract}

Penguatan Modal Sosial Kelembagaan dalam Penanggulangan Kemiskinan Perdesaan di Pantai Utara dan 
desa, dan petugas penyuluh menjadi penting untuk keberlanjutan sebuah program pemberdayaan dalam memberikan pembinaan untuk usaha ekonomi produktif masyarakat nelayan baik berupa pembinaan teknis maupun manajemen usaha. (e) perlu "pembinaan" pasca program oleh instansi yang berkompeten; (f) perlunya pemberdayaan masyarakat miskin lewat peningkatan koordinasi antar lembaga penanggulangan kemiskinan.

Kata Kunci :Penguatan Modal Sosial, Kemiskinan, Pemberdayaan Nelayan.

\begin{abstract}
This study aims to study the social capital role of poor fishermen's activities and to study the social network of fishermen communities and their institutions. This research uses mixed method, namely qualitative and quantitative. The results showed that natural capital in the eleven sample villages is coastal and oceanic, and the majority of the population with formal education has not graduated from elementary school (SD) and low incomes, Smooth interactions between the rulers and laborers are supported by social relationships based on neighborhood, kinship and religious ties, power transfer only occurs in the level of local institutions that is dominated by close groups of power; and there is relatively no social learning process, because the program activities are more economical. The strength of non-material culture or social capital is an important factor in why the people in the eleven sample villages can still survive. The meaning of mutual trust is the result of interactions involving (at least three) community members in a neighboring group, hamlet level associations, village level organizations, and the development of a social network system across village boundaries. (f) Empowerment programs in poverty reduction efforts are influenced by the strength of social capital generated by a number of values (composite) that form networks of mutual trust, mutual respect and mutual benefits.Recommendations that can be given: (a) strengthening social capital such as shame / self-esteem, empathy, honesty, trustworthiness, altruism, being forward-looking and being rational are important; while the driving force for material progress is hard and diligent work, frugal, passionate about innovation, respect for work performance, visionary, and rational. The two combined values, namely for strengthening social capital on the one hand and for driving progress or strengthening material capital on the other hand, collectively (synergistically) are needed in the management of sustainable programs in rural areas. (b) empowerment of rural communities, especially poor fishermen, through strengthening social capital needs to be put in the framework of the transformation or sustainable development of rural communities (c) the development of coastal areas must pay attention to social relations in fishing communities, so as not to lead to social polarization. (d) the factor of village leadership and extension officers is important for the sustainability of an empowerment program in providing guidance for the productive economic business of the fishing community in the form of technical guidance and business management. (e) need post-program "coaching" by the competent agency; (f) the need for empowerment of the poor through increased coordination between poverty alleviation agencies.
\end{abstract}

Keywords: Strengthening Social Capital, Poverty, Fishermen Empowerment

\section{PENDAHULUAN}

Kesenjangan pembangunan yang selama ini terjadi, sepertinya merupakan perbedaan bawaan sumber daya fisik maupun sumber daya sosial (endowmen).
Terabaikannya pembangunan sumber daya sosial akan menyebabkan lemahnya modal sosial, seperti lemah rasa percaya, jaringan kerja yang tidak efisien, lemahnya norma 
maupun hilangnya nilai-nilai bersama (Agusta, 2000).

Menurut Putnam (1993) dan Fukuyama (1995) perbedaan rasa saling percaya menjadi faktor penyebab adanya perbedaan pembangunan pada suatu wilayah. Selain itu rasa percaya juga merupakan komponen modal sosial yang dapat meningkatkan akses masyarakat kepada sumber-sumber kesejahteraan (Grootaert,1997).Definisi modal sosial secara sederhana menurut Fukuyama (1999) adalah

"an instantiated informal norm that promotes co-operation between two or more individuals. By this definition, trust, networks, civil society, and the like, which have been associated with social capital, are all epiphenominal, arising as a result of social capital but not constituting social capital itself".

Modal sosial memiliki peran yang sangat penting pada beberapa kelompok masyarakat dalam berbagai aktivitas. Namun Fukuyama juga mengatakan bahwa tidak semua norma, nilai dan budaya secara bersama-sama dapat saling melengkapi untuk mendukung pertumbuhan ekonomi. Sama seperti halnya modal fisik dan modal finansial, modal sosial juga bisa menimbulkan dampak negatif. Fukuyama (1999) mengatakan bahwa modal sosial dibangun oleh kepercayaan-kepercayaan antar individu. Rasa saling percaya dibentuk dalam waktu yang tidak sebentar serta memerlukan proses-proses sosial yang berliku.

Modal sosial merupakan salah satu syarat bagi tercapainya kesejahteraan rumah tangga, maupun kemakmuran masyarakat pada umumnya. Modal Sosial dapat dipandang sebagai sebuah jalinan kerja sama antar warga untuk menghasilkan tindakan kolektif untuk tujuan bersama. Tentu dalam melaksanakan tindakan, sepertinya mempunyai nilai- nilai dan akar tradisi yang kuat dalam suatu komunitas dan kemudian dapat dilembagakan menjadi sebuah kebiasaan. Menurut Loury (dalam Coleman, 2009: 415) modal sosial adalah

"kumpulan sumber yang melekat dalam relasi keluarga dan dalam organisasi sosial komunitas dan yang bermanfaat untuk perkembangan kognitif dan sosial anak-anak atau pemuda. Sumbersumber ini berbeda untuk orang yang berbeda dan dapat memberikan keuntungan penting untuk perkembangan modal manusia anakanak dan orang dewasa".

Diketahui bahwa masyarakat pedesaan di Jawa Tengah memiliki nilainilai sosial dan modal sosial yang mengatur pola dan semangat hidup yang di dasarkan pada kepercayaan, keterbukaan, saling peduli, saling menghargai, dan saling menolong diantara anggota kelompok masyarakat.

Di Jawa Tengah gotong royong, tolong menolong di tingkatan praksis dapat dilihat pada bentuk kegiatan masyarakat seperti halnya kegiatan keagamaan, kedukaan, perkawainan, dan aktivitas pemenuhan kebutuhan dasar hidup manusia lainnya misalnya, kesehatan, pendidikan, dan kebutuhan ekonomi lainnya. Dengan adanya modal sosial atau kelembagaan ini, tentu masyarakat akan merasa lebih mudah dalam mengerjakan setiap aktivitasnya yang berhubungan dengan pekerjaan mereka. Aktivitas lebih bersifat sukarela, siapa saja dapat mengikutinya.

Menurut Rahmat (2008), dalam tulisannya memupuk institusi lokal dan modal sosial dalam Kehidupan Bermasyarakat dapat dilakukan melalui pengorganisasian institusi diarahkan dalam rangka memfasilitasi komunitas lokal. Mengembangkan kerangka fikir re-lingking (menyambung kembali) tindakan ini diarahkan untuk menyambung kembali titik temu dimensi 
formal dengan dimensi nonformal yang ada di dalam masyarakat. Perbaikan infrastruktur dalam suasana religius dan cultural

Upaya Pemerintah untuk menanggulangi kemiskinan, pada prinsipnya mempunyai dua tujuan utama yaitu meningkatkan kesejahteraan masyarakat miskin dan meningkatkan peran lembaga lokal menjadi lembaga yang mandiri sebagai pengelola program pasca program pemerintah dihentikan.

Sementara itu kelembagaan yang dibangun oleh program pada umumnya bersifat horizontal, lemah secara vertikal, oleh karena itu persoalan modal sosial yang diindikasikan dalam sebuah kelembagaan yang hidup di masyarakat menjadi sangat penting dalam mendukung keberhasilan program.

Untuk mengetahui lebih dalam bagaimana social capital kelembagaan yang ada di masyarakat perdesaan terutama dalam penanggulangan kemiskinan di desa-desa nelayan maka diperlukan penelitian. Pertama, bagaimana peran social capital dan institusi lokal pada aktivitas nelayan miskin di pantai utara dan pantai selatan Jawa Tengah. Kedua, bagaimana jaringan sosial masyarakat, nelayan di pantai utara dan pantai selatan Jawa Tengah. Ketiga, bagaimana kelembagaan-kelembagaan yang dibangun untuk kegiatan pemberdayaan masyarakat nelayan terutama kelembagaan ekonomi. Keempat, bagaimana merumuskan dan menyusun gambaran model pengembangan kelembagaan untuk pemberdayaan nelayan miskin di pantai selatan dan pantai utara Jawa Tengah

\section{METODE}

Penelitian ini menggunakan metode penelitian mixed method kualitatif dan kuantitatif. Menurut Sugiyono (2011:18) mixed methods adalah metode penelitian dengan mengkombinasikan antara dua metode penelitian sekaligus, kualitatif dan kuantitatif dalam suatu kegiatan penelitian, sehingga akan diperoleh data yang lebih komprehensif, valid, reliabel, dan objektif. Penelitian ini didesain dengan menggunakan pendekatan deskriptif. Teknik pengumpulan data ini adalah dengan wawancara,observasi dan dokumentasi. Analisis dalam penelitian ini dilakukan melalui dua tahap, yaitu pertama mempersempit fokus, menetapkan tipe studi, mengembangkan pertanyaan analitik, menyusun komentar, dan telaah kepustakaan yang relevan. Kedua, membuat kategori-kategori masalah/ temuan dari lapangan dengan cara menata sekuensi atau urutan penelaahannya.

Populasi dalam penelitian ini meliputi desa-desa di Provinsi Jawa Tengah yang telah menyelenggarakan program-program penanggulangan kemiskinan pada tahun 2015 sampai 2018, sedangkan sampel penelitian diambil secara purposive (ditentukan selaras dengan tujuan studi). Informan dalam penelitian ini adalah para pihak yang terlibat dalam pelaksanaan program penanggulangan kemiskinan di tingkat desa, kecamatan dan kabupaten dari unsur pemerintah dan/ atau pemangku kepentingan lainnya seperti kelompok nelayan, tokoh masyarakat, ketua RT, ketua RW, kepala dusun, ketua Badan Permusyawaratan Desa, Petugas Sosial Masyarakat, Petugas Penyuluh Pertanian dalam arti luas, Kepala Urusan Pembangunan Kecamatan, Petugas Bappeda Kabupaten.

\section{HASIL DAN PEMBAHASAN \\ Gambaran Umum Desa Sampel}

Kabupaten Kebumen, Brebes, Batang dan Rembang merupakan kabupaten yang memiliki daerah pantai dan laut cukup luas. Kondisi eksisting sebagian modal alam (natural capital) 
pada sebelas desa sampel berupa pesisir dan lautan, sebagian besar usaha penangkapan ikan sebagai nelayan, kecuali itu hanya sebagian kecil lahan sawah, usaha pertanian di dua desa lainnya di pantai selatan.

Secara keseluruhan bisa dibuat penilaian bahwa dibanding enam desa sampel lainnya, kemajuan ekonomi pada masyarakat Desa Tasikagung paling tinggi, kemudian disusul Desa Kluwut, Desa Klidang Wetan, Pasir dan Kedawung, Tanjungsari dan Karang Duwur.

Penguasaan alat produksi penangkapan ikan secara formal ini terlihat pada pemilikan perahu oleh beberapa nelayan. Penguasaan alat produksi penangkapan ikan secara efektif terlihat pada nelayan yang menangkap ikan menggunakan perahu bantuan P3EMDN. Nelayan yang menguasai alat produksi penangkapan ikan secara formal umumnya disebut sebagai "juragan", sedangkan nelayan yang bekerja pada nelayan juragan disebut sebagai "buruh".

Hubungan antar lapisan sosial nelayan tidak berjarak dan tidak menimbulkan permusuhan di antara nelayan. Semua nelayan sama sekali tidak merasa keberatan untuk menerima dan bekerja sama dengan nelayan yang berasal dari lapisan yang berbeda.

Aset non penangkapan ini mencakup : a) Penguasaan alat produksi pertanian, perikanan budidaya, dan peternakan. Perbedaan penguasaan lahan persawahan, penguasaan perikanan budidaya dan jumlah serta jenis ternak ternyata tidak menimbulkan kesenjangan di antara lapisan nelayan; b) Tingkat pendapatan. Sebagian besar rumah tangga nelayan di desa-desa nelayan pantai utara maupun pantai selatan berpendapatan rendah dan masuk pada golongan ekonomi lemah. Penguasaan alat produksi penangkapan ikan bukan merupakan faktor penentu terhadap tingkat pendapatan sebagian besar nelayan. Upaya untuk menutupi kebutuhan sehari-hari dengan melakukan pekerjaan serabutan, sebagai petani atau buruh tani, pedagang ikan, wirausaha atau warungan, pertukangan, mengirim anggota keluarga sebagai TKW/TKI. c) Keadaan Rumah dan Pekarangan. Penguasaan alat produksi penangkapan ikan ternyata bukan merupakan faktor penentu keadaan rumah dan isinya. Keadaan rumah tidak melambangkan identitas lapisan sosial nelayan. Rata-rata luas lahan pekarangan yang dikuasai oleh masing- masing lapisan nelayan hampir sama sehingga tidak ada kesenjangan di antara nelayan. Keadaan rumah dan isinya serta luas penguasaan lahan pekarangan bukan merupakan faktor penentu dalam pembentukan stratifikasi sosial nelayan.

Masyarakat nelayan di sebelas desa sampel masih mencerminkan budaya atau peradaban masyarakat agraris. Tampak bahwa persepsi nelayan tentang program pemberdayaan masyarakat memberikan gambaran yang positif. Nelayan di desa yang tidak terdapat program pemberdayaan masyarakat, memiliki persepsi yang relatif kurang positif dibanding nelayan yang terkena program pemberdayaan masyarakat.

\section{Peran Modal Sosial}

Walaupun tidak semua tingkat kehidupan masyarakat di kesebelas desa sampel mengalami kemajuan, atau setidak-tidaknya ada yang kemajuannya mengalami masa pasang surut, namun secara sosio-historis masyarakat di sebelas desa sampel memiliki kekuatan untuk tetap bertahan hidup dan sekaligus menghindarkan diri dari proses pemusnahan secara alami. Ini menunjukkan bahwa keberadaan masyarakat pedesaan tidak sekedar adanya sekumpulan manusia yang secara fisik 
telah hidup bersama dalam kurun tertentu, melainkan ada "semangat" atau ruh sosial yang menjadi kekuatan pengikat kehidupan kolektif mereka.

Modal sosial di setiap desa sampel memiliki kekuatan yang berbeda. Desa yang memiliki modal sosial paling kuat adalah Desa Tasikagung (4,01). Desa yang memiliki modal sosial yang tergolog antara sedang dan kuat adalah Klidang Lor $(3,47)$ Desa Pasir, Dukuh Celong Desa Kedawung, Desa Kluwut, Desa Karang Duwur dan Tanjungsari. Sedangkan desa yang memliki modal sosial tergolong lemah $(2,53)$ yaitu desa Prapak Lor, Prapak Kidul,Klidang Wetan dan Pandangan.

Tabel 1

Kekuatan Modal Sosial Menurut Elemen Pembentuknya serta Kesebelas Desa Sampel.

\begin{tabular}{|c|c|c|c|c|c|c|c|c|c|c|c|}
\hline $\begin{array}{l}\text { Elemen Modal } \\
\text { Sosial }\end{array}$ & Pasir & $\begin{array}{c}\text { Kr. } \\
\text { Duwur }\end{array}$ & $\begin{array}{l}\text { Prapak } \\
\text { Lor }\end{array}$ & $\begin{array}{c}\text { Prapak } \\
\text { Kidul }\end{array}$ & Kluwut & $\begin{array}{l}\text { Klidang } \\
\text { Wetan }\end{array}$ & $\begin{array}{l}\text { Klidang } \\
\text { Lor }\end{array}$ & $\begin{array}{l}\text { Keda } \\
\text { wung }\end{array}$ & $\begin{array}{l}\text { Tasik } \\
\text { agung }\end{array}$ & $\begin{array}{c}\text { Tanjung } \\
\text { sari }\end{array}$ & $\begin{array}{c}\text { Panda } \\
\text { ngan }\end{array}$ \\
\hline Pemerintahan & 2,50 & 2,50 & 3.00 & 3.00 & 3.00 & 2,50 & 3.00 & 2.50 & 4.00 & 3.00 & 3.00 \\
\hline Kepemimpinan & 3.63 & 3.50 & 3.00 & 3.50 & 3.50 & 2.00 & 4.00 & 2.00 & 4.25 & 4.00 & 3.50 \\
\hline Elit-Anak buah & 3.50 & 3.38 & 3.50 & 3.50 & 3.50 & 2.25 & 4.14 & 2.00 & 3.00 & 3.00 & 3.88 \\
\hline Solidaritas & 4.25 & 2.00 & 3.00 & 3.88 & 3.50 & 2.00 & 4.00 & 3.00 & 3.00 & 2.71 & 4.00 \\
\hline Gotongroyong & 4.00 & 3.00 & 3.00 & 4.00 & 3.50 & 2.00 & 3.00 & 3.00 & 3.00 & 3.00 & 3.86 \\
\hline $\begin{array}{l}\text { Manajemen } \\
\text { Sosial }\end{array}$ & 1.00 & 3.00 & 3.00 & 1.00 & 2.14 & 2.14 & 3.00 & 2.00 & 4.00 & 2.80 & 4.00 \\
\hline Jaringan Kerja & 4.00 & 2.71 & 3.18 & 3.89 & 1,98 & 1,98 & 3.29 & 2.00 & 4.30 & 3.35 & 3.89 \\
\hline
\end{tabular}

Keterangan: $1=$ sangat lemah $2=$ lemah $3=$ sedang $4=$ kuat $5=$ sangat kuat

Tabel 2.

Kekuatan Kepemimpinan Masyarakat di Tingkat Dukuh dan Desa Menurut Komponen Pembentuknya.

\begin{tabular}{|c|c|c|c|c|c|c|c|c|c|c|c|}
\hline $\begin{array}{l}\text { Elemen Kepemim } \\
\text { pinan }\end{array}$ & Pasir & $\begin{array}{c}\text { Kr. } \\
\text { Duwur }\end{array}$ & $\begin{array}{l}\text { Prapak } \\
\text { Lor }\end{array}$ & $\begin{array}{c}\text { Prapak } \\
\text { Kidul }\end{array}$ & $\begin{array}{l}\text { Klu } \\
\text { wut }\end{array}$ & $\begin{array}{l}\text { Klidang } \\
\text { Wetan }\end{array}$ & $\begin{array}{c}\text { Kli } \\
\text { dang } \\
\text { Lor }\end{array}$ & $\begin{array}{l}\text { Keda } \\
\text { wung }\end{array}$ & $\begin{array}{r}\text { Tasik } \\
\text { agung }\end{array}$ & $\begin{array}{l}\text { Tanjung } \\
\text { sari }\end{array}$ & $\begin{array}{c}\text { Panda } \\
\text { ngan }\end{array}$ \\
\hline Visi ke depan & 3 & 3 & 3 & 3 & 3 & 3 & 3 & 3 & 3 & 3 & 3 \\
\hline Motivasi & 3 & 3 & 2 & 3 & 3 & 2 & 3 & 4 & 4 & 3 & 2 \\
\hline Altruistik & 3 & 2 & 3 & 3 & 3 & 2 & 3 & 2 & 3 & 2 & 2 \\
\hline Inspiring & 2 & 3 & 2 & 3 & 3 & 2 & 3 & 2 & 3 & 3 & 2 \\
\hline Kemampuan khusus & 3 & 3 & 2 & 2 & 2 & 2 & 3 & 2 & 3 & 2 & 2 \\
\hline Komunikasi & 3 & 3 & 2 & 3 & 3 & 2 & 3 & 2 & 3 & 2 & 3 \\
\hline Solidarity maker & 3 & 3 & 3 & 2 & 3 & 2 & 3 & 3 & 4 & 4 & 3 \\
\hline Rasional & 3 & 3 & 3 & 3 & 3 & 2 & 3 & 2 & 3 & 3 & 3 \\
\hline Demokratik & 3 & 2 & 3 & 3 & 3 & 3 & 3 & 3 & 4 & 4 & 3 \\
\hline
\end{tabular}

Keterangan : 1 sangat lemah; $2=$ lemah; 3 = sedang; $4=$ kuat; $5=$ sangat kuat

Terbentuknya modal sosial tidak bisa dipandang sebagai hasil penjumlahan sekumpulan (kekuatan) individu pembentuk sistem masyarakat, melainkan harus dipandang sebagai terbentuknya jaringan kerja sama yang dinamik dan terorganisir.

Keterbelakangan masyarakat pedesaan terkait erat dengan lemahnya modal sosial. Kemiskinan merupakan bentuk paling akhir terjadinya kerusakan lingkungan dan lemahnya modal sosial di pedesaan.
Terdapat hubungan erat antara kuatnya modal sosial yang dipunyai satu masyarakat dengan kemampuan mengatasi kemiskinan dan kemampuan mengelola program pemberdayaan. Dengan kuatnya modal sosial paling tidak harapan dipenuhinya tujuan pembangunan pedesaan berkelanjutan, yaitu berupa pemenuhan kebutuhan dasar atau keadilan sosial, relatif mudah diatasi.

Keberhasilan pengelolaan program pemberdayaan masyarakat di daerah 
nelayan dapat dilihat dari sejauh mana kesejahteran masyarakat pedesaan dapat dicapai. Jika kemampuan menyekolahkan anak hingga SMP ditambahkan sebagai ukuran, maka > 70 persen penduduk di kesebelas desa contoh berada dibawah garis kemiskinan.

\section{Jaringan Sosial dan Kelembagaan}

Ada tiga aspek yang menunjukkan penguatan modal sosial yaitu: terbentuknya kerjasama dan solidaritas (kohesivitas), perluasan jaringan kerja dan peningkatan daya saing kolektif secara berkelanjutan. Di lapangan teramati bahwa ketiga kekuatan modal sosial tersebut dibangkitkan oleh sejumlah tata nilai (komposit) yang membentuk jaringan mutual trust, mutual respect dan mutual benefit. Nilai-nilai rasa malu atau harga diri, empati, kejujuran, amanah dan altruisme merupakan komponen modal sosial yang strategis. Nilai-nilai pembentuk modal sosial lainnya, seperti kerja keras, kerajinan, hemat, gandrung inovasi, menghargai prestasi, ber-visi ke depan, dan rasional sangat penting untuk menciptakan kemajuan atau pertumbuhan (ekonomi) pada budaya material. Akan tetapi hal tersebut tidak mencukupi untuk menciptakan kerangka penguatan modal sosial kelembagaan dalam rangka penanggulangan kemiskinan melalui program-program pemberdayaan masyarakat di daerah nelayan.

Penguatan modal sosial dalam rangka penanggulagan kemiskinan di pedesaan nampaknya tidak terbatas pada kelembagaan, namun perlu juga terhadap modal sosial yang lain. Pemberdayaan masyarakat untuk penanggulangan kemiskinan di pedesaan secara berkelanjutan tidak cukup didasarkan pada pemberian bantuan material berdasar semangat belas kasihan (charitas) atau pengembangan sistem usaha atau produksi berbasis sumberdaya alam yang tersedia (laut) saja, melainkan harus juga mempertimbangkan penguatan semangat kerja kolektif dan menghormati sumberdaya (agro ekosistem) sebagai milik bersama.

Tabel 3.

Model Hubungan antara Tingkat Masyarakat, Dimensi Waktu dan Elemen Modal Sosial yang Mungkin Diubah dan Dikuatkan melalui Percepatan Transformasi Sosial di Pedesaan Dimensi Elemen yang diubah menurut tingkat masyarakat (level of society) Dalam Waktu proses penguatan modal sosial di pedesaan

\begin{tabular}{|c|c|c|c|}
\hline & $\begin{array}{c}\text { Mikro } \\
\text { Individu }- \text { Kel Kecil }\end{array}$ & $\begin{array}{c}\text { Meso } \\
\text { (Kel. Kecil - } \\
\text { Desa/Dukuh) }\end{array}$ & $\begin{array}{c}\text { Makro } \\
\text { (Masyarakat } \\
\text { Tk.Kecamatan) }\end{array}$ \\
\hline Jangka & Tipe 1 & Tipe 3 & Tipe 5 \\
\hline pendek & $\begin{array}{l}\text { Kompetensi SDM } \\
\text { (1) Sikap dan tindakan } \\
\text { (2) Tata Nilai }\end{array}$ & $\begin{array}{c}\text { (1) Tata nilai } \\
\text { (normative) } \\
\text { (2) Administratif dan } \\
\text { manajemen sosial }\end{array}$ & $\begin{array}{l}\text { (1) Invensi - inovasi } \\
\text { (2) Revolusi dan } \\
\text { kepemimpinan }\end{array}$ \\
\hline
\end{tabular}

\begin{tabular}{|c|c|c|c|}
\hline Jangka & Tipe 2 & Tipe 4 & Tipe 6 \\
\hline Panjang & $\begin{array}{c}\text { Siklus kebiasaan dan } \\
\text { gaya hidup individual/ } \\
\text { keluarga kelompok } \\
\text { kecil }\end{array}$ & $\begin{array}{l}\text { Tatanilai (kolektif), } \\
\text { kepemimpinan, } \\
\text { solidaritas,struktur dan } \\
\text { organisasi sosial }\end{array}$ & $\begin{array}{c}\text { Evolusi modal sosial/ } \\
\text { dan sosio budaya secara } \\
\text { menyeluruh }\end{array}$ \\
\hline
\end{tabular}

Keterangan: Model dikembangkan dari pemikiran Zaltman and Duncan (1977) 
Kelemahan utama pemberdayaan masyarakat pedesaan selama ini karena terlalu menekankan pada penguatan modal prasarana, penggunaan jaringan organisasi keproyekan dan pemerintahan yang bersifat sentralistik, top - down, dan monolitik.

Tabel tersebut diatas menggambarkan kerangka atau model penguatan modal sosial untuk pemberdayaan masyarakat dalam pengelolaan program-program pemberdayaan dalam rangka penanggulangan kemiskinan yang dianggap sesuai adalah yang mengacu pada Tipe 6. Hanya saja untuk mencapai Tipe 6 perlu ditempuh langkah-langkah Tipe 3 dan Tipe 4 yang dicirikan oleh pentingnya memperkuat modal sosial melalui kekuatan kelompok kecil pada masyarakat tingkat desa dan lebih kecil lagi tingkat dukuh. Langkah yang ditempuh Tipe 1 dan Tipe 2 dinilai akan banyak menyita tenaga dan biaya, yang hasilnya diperkirakan tidak bisa memperkuat modal sosial termasuk didalamnya kelembagaan di tingkat desa secara langsung. Dalam kaitan ini peran pemerintah seyogyanya dipandang sebagai representasi campur tangan publik untuk memenuhi kebutuhan dan melayani kepentingan masyarakat banyak pedesaan.

\section{KESIMPULAN DAN REKOMENDASI Kesimpulan}

(1) Nelayan di Desa sampel sebagian besar berpendidikan formal tidak tamat Dasar (SD) dan berpendapatan rendah (2) Hubungan sosial nelayan berdasarkan ikatan ketetanggaan, kekerabatan, dan keagamaan masih kuat. Berbagai upacara keagamaan yang didasarkan atas tradisi Islam setempat, seperti tahlilan, kenduren, ruwahan, dan pengajian masih dilakukan pada saat-saat tertentu (3) Stratifikasi sosial nelayan didasarkan atas kriteria obyektif (penguasaan alat produksi penangkapan, penguasaan lahan pertanian, dan usia) dan subyektif (persepsi nelayan). Nelayan berdasarkan penguasaan alat produksi penangkapan terbagi menjadi 2 strata, yaitu nelayan yang menguasai alat produksi penangkapan (juragan) dan yang tidak menguasai (buruh). Nelayan berdasarkan penguasaan lahan pertanian tidak ada strata, karena nelayan hanya menguasai lahan rerata 1,5 iring $\left(2500 \mathrm{~m}^{2}\right.$ ). Nelayan yang berusia di atas 30 tahun mayoritas merupakan nelayan jaring eret dan nelayan sungai, sedangkan nelayan yang berusia di bawah 30 tahun mayoritas merupakan nelayan perahu motor tempel (4) Nelayan berdasarkan kriteria subyektif terbagi menjadi 2 strata, yaitu nelayan berstrata tinggi apabila menguasai lahan luas, ternak yang banyak, dan atau berjasa di masyarakat dan sebaliknya untuk nelayan berstrata rendah (5) Nelayan bekerja secara individual sebelum adanya perahu motor tempel. Introduksi perahu motor tempel merubah hubungan kerja di antara nelayan, yaitu nelayan menangkap ikan di laut secara berkelompok (2-3 orang per perahu), dengan pembagian kerja yang tidak ketat antara tekong dan buruh (6) Desa yang memiliki modal sosial yang paling kuat adalah Desa Tasikagung (PEMP), kemudian disusul Desa Klidang Lor (PINNES), Celong Kedawung, Pasir dan Karang Duwur. Pada masyarakat desa yang memiliki modal sosial yang relatif kuat maka tingkat kesejahteraaan masyarakat cenderung tinggi dan proses transformasi sosial-ekonominya berlangsung lebih cepat (7) Program pemberdayaan masyarakat nelayan dalam pengelolaan PEMP, P3EMDN selama ini masih lebih menekankan pada pemberian bantuan material, dan kurang pada penguatan modal sosial setempat. Berkembangnya kegiatan ekonomi dan pengelolaan bantuan program setempat lebih dipengaruhi oleh kemampuan masyarakat mengalokasikan sumberdaya 
keluarga dan mengelola tata nilainya untuk memperkuat modal sosialnya dari pada besarnya bantuan material dan pengetahuan teknologis yang diterima nelayan melalui keorganisasian proyek atau pemerintahan desa (8) Desa yang memiliki modal sosial yang paling kuat adalah Desa Tasikagung (PEMP), kemudian disusul Desa Kluwut (Program Departemen Kelautan dan Perikanan), Desa Klidang Lor (PINNES) Desa Pasir (Program Pusat). Pada masyarakat desa yang memiliki modal sosial yang relatif kuat maka tingkat kesejahteraan masyarakatnya cenderung tinggi dan proses transformasi sosial ekonominya berlangsung lebih cepat (9) Beberapa indikator modal sosial dalam pengelolaan program pemberdayaan P3EMDN secara berkelanjutan adalah terletak pada kuat atau lemahnya solidaritas, manajemen sosial, keorganisasian jaringan kerja, struktur sosial dan kegotongroyongan masyarakat setempat. Modal sosial relatif tajam bisa diamati di tingkat masyarakat kecil atau dukuh. Jalinan mutual trust, mutual respect dan mutual benefit, masih ditemukan pada masyarakat dukuh; namun jalinan ini mulai memudar pada masyarakat pedesaan.

\section{Rekomendasi}

Sekumpulan elemen tata nilai yang penting untuk penguatan modal sosial adalah rasa malu/harga diri, empati, kejujuran, amanah, altruism, bervisi ke depan dan rasional; sedangkan untuk penggerak kemajuan material adalah kerja keras dan rajin, hemat, gandrung inovasi, menghargai prestasi kerja, bervisi ke depan, dan rasional. Kedua gabungan tata nilai, yaitu untuk penguatan modal sosial di satu sisi dan untuk penggerak kemajuan atau penguatan modal material di sisi lain, secara bersama (sinergis) dibutuhan dalam pengelolaan PEM, P3EMDN berkelanjutan di Pedesaan.

Pengembangan modal penguatan mosal sosial memerlukan pemahaman yang mendalam tentang penguatan tata nilai keorganisasian masyarakat berbasis komunitas kecil, manajemen sosial yang sehat, kepemimpinan nonformal, dan penyelenggaraan pemerintahan yang baik. Oleh sebab itu, pemberdayaan masyarakat pedesaan terutama warga nelayan miskin melalui penguatan modal sosialnya perlu diletakkan dalam kerangka transformasi atau pembangunan masyarakat pedesaan secara berkelanjutan.

Pengembangan wilayah pesisir harus memperhatikan hubungan sosial dalam masyarakat nelayan, agar tidak mengarah pada polarisasi sosial.

Faktor kepemimpinan desa, dan petugas penyuluh menjadi penting untuk keberlanjutan sebuah program pemberdayaan seperti PEMP pada semua lokasi terutama dalam memberikan pembinaan untuk usaha ekonomi produktif masyarakat nelayan baik berupa pembinaan teknis maupun manajemen usaha.

Banyak kasus tidak terjadinya
keberlanjutan program di pedesaan nelayan disamping kuat atau lemahnya modal sosial, juga oleh karena tidak terjadi "pembinaan" pasca program oleh instansi yang berkompeten;

Perlunya pemberdayaan masyarakat miskin lewat peningkatan koordinasi antar lembaga penanggulangan kemiskinan. 
DAFTAR PUSTAKA

Agusta, I. 2000. Asumsi-asumsi Program Pemberdayaan Masyarakat Pedesaan Indonesia. dalam Mimbar Sosek Th. 12 No. 3 April

Coleman, J.S. 2009. Social Teory, Social Research, and a Theory of Action. The American Jurnal of Sociology

Fukuyama, Francis. 1995. Trust: The Social Virtues and The Creation of Prosperity, New York: theFree Press

1999. Social Capital and Civil Society makalah yang disampaikan pada the IMF

Grootaert, C (1997) 'Social Capital: The missing link?, in Expanding the Measure of Wealth: Indicators of Environmentally Sustainable Development, Washington : World Bank, Environmentally Sustainable
Development Studies and Monographs, Series No. 17, June, pp. $77-93$

Putnam, Robert D., 1993, Making Democracy Work: Civic Traditions in Modern Italy (Princeton, New Jersey: Princenton University Press).

Rahmat, Pupu Saeful. 2008. Memupuk Institusi Lokal dan Modal Sosial dalam Kehidupan Bermasyarakat. https://akhmadsudrajat.wordpress.c om/2008/03/29

Sugiyono. 2011. Metode Penelitian Kuantitatif, Kualitatif dan R\&D. Bandung: Afabeta Zaltman \& Duncan. 1977. Strategies for Planned Change . New York, NY: John Wiley and Sons 